EDITORIAL

\title{
Do we really know who are left behind and who are at risk of being left behind?
}

Open acess

${ }^{1}$ Senior Lecturer in Public health. Graduate Entry Medical School, University of Limerick, Ireland.

${ }^{2}$ Master in health Science. Centro Universitário FMABC, Santo André, Brazil.

${ }^{3} \mathrm{PhD}$, Universidade do Estado de Santa Catarina, SC, Brazil.

\section{Corresponding author:}

khalifa_elmusharaf@yahoo.com

Manuscript received: November 2018 Manuscript accepted: November 2018

Version of record online: November 2018
Khalifa Elmusharaf', Blanca Elena Guerrero Daboin², Tania Brusque Crocetta $^{3}$

\section{Abstract}

There is enough evidence to show the importance of the first 1000 days of life for child survival and development, and the next 8000 days for a child to reach adulthood. Yet discrimination, place of residence, socio-economic status, and inequalities within and between countries contribute to earlier mortality and significant morbidities for mothers and their children, particularly in settings with limited resources. Therefore, many children and adolescents and their families were left behind.

JHGD has been raising public health issues related to inequalities and right to health. In this issue, articles generate debate around human dignity and health disparities. Several articles discuss a verity of health issues particularly in Amazon and Northeast region. School health was also discussed in this issue. Three studies were conducted in schools in Rio Grande do Sul, Brazil.

Research indicate that many children and adolescents are left behind. We are missing many opportunities to bridge the gap of inequality. Actions need to be taken now to make sure no one is left behind.

Keywords: health inequalities, child health, adolescent health, primary healthcare. 
There is enough evidence to show the importance of the first 1000 days of life for child survival and development, and the next 8000 days for a child to reach adulthood. Yet discrimination, place of residence, socio-economic status, and inequalities within and between countries contribute to earlier mortality and significant morbidities for mothers and their children, particularly in settings with limited resources ${ }^{1-4}$. Therefore, many children and adolescents and their families were left behind ${ }^{5}$. The 2011 Rio de Janeiro Political Declaration is a milestone document to achieve social and health equity through action on social determinants of health and well-being by a comprehensive intersectoral approach. This is to be achieved by adopting better governance, promoting participation in policymaking, reorienting the health sector, strengthening global collaboration, monitoring progress and increasing accountability.

The UN Member States agreed on the Sustainable Development Goals (SDGs) by 2030 and pledged to ensure "no one will be left behind". However, to know who are left behind and who are at risk of being left behind, it is important to examine the disadvantages people face. This should be done by collecting data to monitor child and adolescents' health and activities including education, nutrition, mental health ${ }^{6}$, environment, social exclusion? ${ }^{7}$, to name a few. Measuring different aspects of the health of newborns, children and adolescents is essential to track progress towards achieving the aims of the Global Strategy for Women's, Children's and Adolescents' Health 2016-2030'. The current challenge is that many organizations are collecting data that are not always comparable, making the sharing and use of the data complicated. WHO recently formed technical advisory groups to provide a standard set of harmonized indicators for monitoring and reporting on Mother, Newborn, Children and Adolescents. These technical advisory groups are Mother and Newborn Information for Tracking Outcomes and Results (MoNITOR) ${ }^{9}$, Adolescent Health Metrics (AHM) ${ }^{10}$, and Child Health Accountability Tracking (CHAT) ${ }^{11}$.

The Declaration of Alma-Ata in 1978 formed the foundation for the last 40 years of global primary health care (PHC) efforts. The recently signed Astana Declaration ${ }^{12} 2018$ on PHC declared that PHC approach is still the most effective way to sustainably solve today's health and health system challenges ${ }^{13}$. The investment in PHC is the smarter investment, because of its low cost and its high return on investment. The new declaration renewed the political commitment to PHC and will inform the UN General Assembly high-level meeting on Universal Health Coverage UHC in 2019. It declares that the success of primary health care will be driven by capacity-building, human resources, technology, financing, individuals and community empowerment, and stakeholder alignment ${ }^{12}$.

After Brazil created the Unified Health System (SUS, or Sistema Único de Saúde) at the end of 80s, it has worked persistently in breaking the paradigm of a curative health model to move to a preventive health care model reinforcing the importance of primary care. The introduction of the Family Health programme (PSF or Programa Saúde da Família) in 1994, then evolved into the Family Health Strategy (ESF, or Estratégia de Saúde da Família) helped to reduce inequalities among remote areas and groups of greater vulnerability.

During this journey, most important health indicators in Brazil have been improved. Under 5 mortality decreased from 52.5 to 17 per 1000 live births between 1990 and 2015 representing a reduction of $67.7 \%{ }^{14}$. However, despite the improvements observed, the inequality between regions persists. In 2015, among the 13 states with the highest than national average under-5 mortality rates, six were in Amazon region and seven were in Northeast region ${ }^{14}$.

JHGD has been raising public health issues related to inequalities and right to health. In this issue, Messetti PAS and Dallari DA ${ }^{15}$ examined human dignity in Brazil in the light of the constitution, human rights and bioethics to present a deeper investigation about the social nature of human dignity and its definition over time. Hani K. Atrash ${ }^{16}$ looked at health disparities in the United States including challenges, opportunities, and what can be done about It. Ảine de Roiste ${ }^{17}$ presented a brief exploration of resilience and child development.

This issue brings eight articles from Amazon and Northeast region that address a verity of issues in these two regions. Issues investigated were congenital Zika ${ }^{18}$, neuropsychomotor development ${ }^{19}$, metabolic syndrome ${ }^{20}$, Chagas disease (American Trypanosomiasis $)^{21}$, physical violence ${ }^{22}$, tuberculosis control $^{23}$, scorpion stings and spider bites ${ }^{24}$ and patient safety culture ${ }^{25}$.

Garner DM et al. ${ }^{26}$ assessed the heart rate dynamics in young obese subjects by nonlinear metrics to heart rate variability. ZangirolamiRaimundo $\mathrm{J}$ et al. ${ }^{27}$ presented a useful research 
methodology article on cross-sectional studies.

School health was also discussed in this issue.

Three studies were conducted in schools in Rio Grande do Sul, Brazil to investigate the relationship between dietary intake and nutritional status with school performance ${ }^{28}$, to examine the occurrence of metabolic risk in School children using waist and height ratio ${ }^{29}$ and to assess the impact of untreated dental caries on oral health of adolescents ${ }^{30}$.

Research indicate that many children are left behind. We are missing opportunities to bridge the gap of inequality. One of these opportunities could be the appropriate use of technology. Examples of new technology are games with virtual reality for rehabilitation ${ }^{31}$, recovery of children with Duchenne muscular dystrophy ${ }^{32}$, inclusion of older people ${ }^{33}$, or improving literacy of individuals with intellectual disabilities $^{34}$. The advancement of the "Internet of Things" (IoT) technology has a potential to be used in medical and health care, with a development of applications that will change the way of living ${ }^{35}$, especially in remote areas in Brazil.

More research is needed to understand who are left behind and who are at risk of being left behind and why. Actions need to be taken now to make sure that no one is left behind.

\section{REFERENCES}

1. Elmusharaf K, Byrne E, AbuAgla A, AbdelRahim A, Manandhar M, Sondorp E, et al. Patterns and determinants of pathways to reach comprehensive emergency obstetric and neonatal care (CEmONC) in South Sudan: qualitative diagrammatic pathway analysis. BMC Pregnancy Childbirth. 2017;17(1):278. DOI: https://doi.org/10.1186/s12884-017-1463-9

2. Elmusharaf K, Byrne E, O'Donovan D. Social and traditional practices and their implications for family planning: a participatory ethnographic study in Renk, South Sudan. Reprod Health. 2017;14:10. DOI: https://doi.org/10.1186/s12978-016-0273-2

3. Elmusharaf K, Byrne E, Manandhar M, Hemmings J, O'Donovan D. Participatory Ethnographic Evaluation and Research: Reflections on the Research Approach Used to Understand the Complexity of Maternal Health Issues in South Sudan. Qual Health Res. 2017;27(9):1345-58. DOI: https://doi.org/10.1177/1049732316673975

4. Elmusharaf K, Byrne E, O'Donovan D. Strategies to increase demand for maternal health services in resource-limited settings: challenges to be addressed. BMC Public Health. 2015;15:870. DOI: https://doi.org/10.1186/s12889-015-2222-3

5. United Nations Development Programme (UNDP). What Does It Mean To Leave No One Behind? A UNDP discussion paper and framework for implementation 2018. [cited 2018 Oct 28] Available from: http://www.undp.org/content/dam/undp/library/Sustainable\%20Development/2030\%20Agenda/ Discussion_Paper_LNOB_EN_Ires.pdf.

6. Smyth BP, Elmusharaf K, Cullen W. Opioid substitution treatment and heroin dependent adolescents: reductions in heroin use and treatment retention over twelve months. BMC Pediatrics. 2018;18(1):151. DOI: https://doi.org/10.1186/s12887-018-1137-4

7. O'Donnell P, O'Donovan D, Elmusharaf $K$. Measuring social exclusion in healthcare settings: a scoping review. Int J Equity Health. 2018;17(1):15. DOI: https://doi.org/10.1186/s12939-018-0732-1

8. United Nation Every Woman Every Child. The Global Strategy for Women's, Children's and adolescente Health (2016-2030). [cited 2018 Oct 28] Available from: http://www.who.int/life-course/partners/globalstrategy/globalstrategyreport2016-2030-lowres.pdf.

9. World Health Organization (WHO). Mother and Newborn Information for Tracking Outcomes and Results (MONITOR) technical advisory group. [cited 2018 Oct 28] Available from: http://www.who.int/maternal_ child_adolescent/epidemiology/monitor/en/.

10. World Health Organization (WHO). Advisory Group for Adolescent Health Metrics. [cited 2018 Oct 28] Available from: http://www.who.int/reproductivehealth/advisory-group-adolescenth-health-metrics/en/.

11. World Health Organization (WHO). Child Health Accountability Tracking (CHAT) Technical Advisory Group. [cited 2018 Oct 28] Available from: http://www.who.int/maternal_child_adolescent/child/TAG-childhealth-accountability-tracking.pdf.

12. World Health Organization (WHO). Declaration of Astana on Primary Health Care. WHO/HIS/ SDS/2018.61. [cited 2018 Oct 28] Available from: https://www.who.int/docs/default-source/primary-health/ declaration/gcphc-declaration.pdf. 
13. World Health Organization (WHO). WHO, UNICEF: A Vision For Primary Health Care In The 21st Century: Towards universal health coverage and the sustainable development goals (WHO/HIS/ SDS/2018.X). [cited 2018 Oct 28] Available from: https://www.who.int/docs/default-source/primary-health/ vision.pdf

14. França EB, Lansky S, Rego MAS, Malta DC, França JS, Teixeira R, et al. Leading causes of child mortality in Brazil, in 1990 and 2015: estimates from the Global Burden of Disease study. Rev Bras Epidemiol. 2017;20 (Suppl 1):46-60. DOI: https://doi.org/10.1590/1980-5497201700050005

15. Messetti PAS, Dallari DA. Human dignity in the light of the Constitution, human rights and bioethics. J Hum Growth Dev. 2018;3(28):283-9. DOI: http://doi.org/10.7322/jhgd.152176

16. Atrash HK. Health Disparities: Challenges, Opportunities, and What You Can Do About It. J Hum Growth Dev. 2018;28(3):223-31. DOI: https://doi.org/10.7322/jhgd.152156

17. Roiste Ả. Nurturing resilience: the 'ordinary magic' of everyday life. J Hum Growth Dev. 2018;28(3):27882. DOI: http://doi.org/10.7322/jhgd.152175

18. Fontes ACPL, Bezerra IMP, Abreu LC. Description of atypical pattern in twins with presumed congenital Zika and without microcephaly - Case Report. J Hum Growth Dev. 2018;28(3):353-60. DOI: http://doi.org/10.7322/jhgd.152196

19. Pantoja APP SG, Nunes EFC, Pontes LS. Effect analysis of environmental factors on the children's Amazon community neuropsychomotor development. J Hum Growth Dev. 2018;28(3):232-9. DOI: https://doi.org/10.7322/jhgd.152158

20. Sousa LVA ME, Quaresma FRP, Abreu ACG, Paiva LS, Fonseca FLA, Adami F. Quality of Life and Metabolic Syndrome in Brazilian quilombola communities: A Cross-sectional Study. J Hum Growth Dev. 2018;28(3):316-28. DOI: http://doi.org/10.7322/jhgd.152182

21. Oliveira GF RM, Castro GVS, Menezes ALR, Lima RA, Silva RPM, et al. Retrospective study of the epidemiological overview of the transmission of Chagas disease in the State of Acre, South-Western Amazonia, from 2009 to 2016. J Hum Growth Dev. 2018;28(3):329-36. DOI: http://doi.org/10.7322/jhgd.152187

22. Carvalho AP, Franca $C$, Menezes VA. Physical violence and alcohol drinking consumption among teenagers. J Hum Growth Dev. 2018;28(3):273-7. DOI: http://doi.org/10.7322/jhgd.152172

23. Santana FM MA, Monhol PP, Azzalis LA, Junqueira VBC, Feder D, et al. Evaluation of the performance of tuberculosis control actions and services of the Family Health Strategies. J Hum Growth Dev. 2018;28(3):342-52. DOI: http://doi.org/10.7322/jhgd.152194

24. Silva EP MW, Bernarde PS,. Scorpion stings and spider bites in the Upper Juruá, Acre - Brazil. J Hum Growth Dev. 2018;28(3):290-7. DOI: http://doi.org/10.7322/jhgd.152178

25. Silva GM LM, Araripe MC, Vasconcelos SP, Opitz SP, Laporta GZ. Evaluation of the Patient Safety Culture in the Western Amazon. J Hum Growth Dev. 2018;28(3):307-315. DOI: http://doi.org/10.7322/jhgd.152192

26. Garner DM VF, Vanderlei LCM. Complex measurements of heart rate variability in obese youths: distinguishing autonomic dysfunction. J Hum Growth Dev. 2018;28(3):298-306. DOI: http://doi.org/10.7322/jhgd.152180

27. Zangirolami-Raimundo J EJ, Leone C. Research methodology topics: Cross-sectional studies. J Hum Growth Dev. 2018;28(3):356-60. DOI: http://doi.org/10.7322/jhgd.152198

28. Schmidt AL SM, Conde SR. Relationship between food consumption, nutritional status and school performance. J Hum Growth Dev. 2018;28(3):240-51. DOI: https://doi.org/10.7322/jhgd.152159

29. Dias AF BC, Lemes VB, Gaya ACA, Gaya AR. Occurrence of metabolic risk in schoolchildren using a noninvasive indicator: waist and height ratio. J Hum Growth Dev. 2018;28(3):252-7. DOI: http://doi.org/10.7322/jhgd.152160

30. Tibolla P, Rigo L. Impact of untreated dental caries on oral health of adolescents from cities in the countryside of Rio Grande do Sul. J Hum Growth Dev. 2018;28(3):258-72. DOI: http://doi.org/10.7322/jhgd.152171

31. Crocetta TB, Araújo LV, Guarnieri R, Massetti T, Ferreira FHIB, Abreu LC, et al. Virtual reality software package for implementing motor learning and rehabilitation experiments. Virtual Reality. 2018;22(3):199209. 
32. Massetti T, Fávero FM, Menezes LDC, Alvarez MPB, Crocetta TB, Guarnieri R, et al. Achievement of virtual and real objects using a short-term motor learning protocol in people with duchenne muscular dystrophy: a crossover randomized controlled trial. Games Health J. 2018;7(2):107-15. DOI: http://doi.org/10.1089/g4h.2016.0088

33. Bezerra IMP, Crocetta TB, Massetti T, Silva TD, Guarnieri R, Meira Jr CM, et al. Functional performance comparison between real and virtual tasks in older adults: A cross-sectional study. Medicine (Baltimore). 2018;97(4):e9612. DOI: http://doi.org/10.1097/MD.0000000000009612

34. Guarnieri R, Crocetta TB, Massetti T, Barbosa RTA, Antão JYFL, Antunes TPC, et al. Test-Retest Reliability and Clinical Feasibility of a Motion-Controlled Game to Enhance the Literacy and Numeracy Skills of Young Individuals with Intellectual Disability. Cyberpsychol Behav Soc Netw. 2018. DOI: http://doi.org/10.1089/cyber.2017.0534

35. Lim S, Kwon O, Lee DH. Technology convergence in the Internet of Things (IoT) startup ecosystem: A network analysis. Telematics Inform. 2018;35(7):1887-99. DOI: https://doi.org/10.1016/j.tele.2018.06.002

\section{Resumo}

Há evidências para mostrar a importância dos primeiros 1000 dias de vida para a sobrevivência e o desenvolvimento da criança e dos próximos 8000 dias para a criança atingir a idade adulta. Entretanto, o local de residência, o status socioeconômico, a discriminação e as desigualdades dentro e entre os países contribuem para a mortalidade precoce e morbidades significativas para as mães e seus filhos, particularmente em ambientes com recursos limitados, sendo que muitas crianças, adolescentes e suas famílias estão em situação de vulnerabilidade. Como contribuição ao campo da saúde pública, o Journal ofHuman Growthand Development (JHGD)tem promovidodiscussões acerca das questões de saúde pública relacionadas às desigualdades e direito à saúde. Nesta edição, os artigos geram debate em torno da dignidade humana e das disparidades desaúde. Diversosartigos discutemaveracidadedasquestões desaúde, particularmente na região amazônica e nordeste. Além de saúde escolar, que também foi discutida nesta edição. Três estudos foram conduzidos em escolas do Rio Grande do Sul, Brasil. Pesquisas indicam que muitas crianças e adolescentes são negligenciados. Estamos perdendo muitas oportunidades para preencher a lacuna da desigualdade. Ações precisam ser tomadas agora para garantir que ninguém seja deixado para trás.

Palavras-chave: desigualdades em saúde, saúde infantil, saúde do adolescente, atenção primária à saúde. 